LETTER TO JMG

\title{
Mutation in kallikrein 4 causes autosomal recessive hypomaturation amelogenesis imperfecta
}

\author{
P S Hart, T C Hart, M D Michalec, O H Ryu, D Simmons, S Hong, J T Wright
}

J Med Genet 2004;41:545-549. doi: 10.1136/jmg.2003.017657

S erine protease functionality is based on nucleophilic attack of a targeted peptidic bond by a serine. The serine protease superfamily is extremely diverse and includes proteases such as plasminogen, prostatin, hepsin, the kallikrein family (KLK genes clustered on chromosome 19.13), and a recently discovered cluster of tryptic-like serine proteases located on human chromosome 16p13. ${ }^{2}$ Serine protease mutations have been reported as causative in only a few autosomal recessive human hereditary conditions, which produce diverse pathological conditions. ${ }^{3}{ }^{4}$ We report the first human kallikrein mutation and describe its association with a rare autosomal recessive form of amelogenesis imperfecta.

The amelogenesis imperfectas are a clinically and genetically heterogeneous group of disorders characterised by faulty development of the tooth enamel due to hypoplasia or hypomineralisation. ${ }^{5}$ The amelogenesis imperfecta phenotypes vary widely depending on the specific gene involved, the location and type of mutation, and the corresponding putative change at the protein level. ${ }^{67}$ The amelogenesis imperfecta enamel defects can be broadly divided into hypoplastic (enamel crystallites do not grow to the correct length) and hypomineralised (crystallites fail to grow in thickness or width) phenotypes. The prevalence of amelogenesis imperfecta varies in different countries (ranging from 1 in 700 in Sweden to 1 in 14000 in the United States) suggesting allele frequency differences between populations. $^{8-11}$ Amelogenesis imperfecta can be inherited as an autosomal dominant, autosomal recessive, or X-linked Mendelian trait. While autosomal dominant amelogenesis imperfecta types are most common in the United States and Europe, autosomal recessive amelogenesis imperfecta types are more common in the Middle East. ${ }^{810} 11$

Dental enamel is the most highly mineralised tissue in the human body with $85 \%$ of its volume occupied by highly organised carbonate substituted hydroxyapatite crystals. ${ }^{12}$ These crystallites are packed into a highly ordered decussating prism pattern giving enamel many of its unique wear and fracture resistant properties. Development of the unique enamel mineral structure and composition is rigorously controlled by the ameloblasts through their secretion of a unique extracellular matrix that is processed in a highly controlled manner. Enamel formation requires the expression of multiple genes that transcribe matrix proteins and proteinases necessary to control the exquisite process of crystal growth and mineralisation. ${ }^{13}{ }^{14}$ The amelogenesis imperfecta associated gene mutations identified to date involve two enamel extracellular matrix molecules: amelogenin (OMIM 300391) and enamelin (OMIM 606585). Amelogenin, the protein product of the AMELX Xq22 and AMELY Ypll, genes, constitutes $90 \%$ of the organic matrix in developing enamel and is considered to be critical for normal enamel thickness and structure. ${ }^{15}$ Enamelin, the protein product of the ENAM gene on chromosome 4q21, is present in comparatively small amounts and undergoes a series of proteolytic cleavages to generate several polypeptides that are thought to participate

\section{Key points}

- Serine proteases play critical roles in numerous regulatory and developmental processes and are expressed in most tissues. Only a few mutations in serine proteinase genes have been identified to date.

- The serine protease superfamily is extremely diverse and includes the kallikrein family (KLK genes clustered on chromosome 19.13).

- We have identified the first mutation in the kallikrein gene family, the KLK4 gene, and have shown this mutation to be associated with autosomal recessive hypomaturation amelogenesis imperfecta.

- The amelogenesis imperfectas are a clinically and genetically heterogeneous group of disorders affecting tooth enamel formation.

- The identified KLK4 gene mutation (g.2142G>A) would result in a truncated kallikrein 4 protein that lacks the S207 of the catalytic triad that is essential for proteolytic activity in this serine proteinase.

- Abnormal kallikrein 4 activity causes the enamel crystallites to grow incompletely in thickness or width but to the normal length. This results in enamel that is of normal thickness but is incompletely mineralised.

in enamel crystal nucleation and extension, and the regulation of crystal habit. ${ }^{16-18}$ Multiple allelic mutations in the genes coding for amelogenin and enamelin are associated with distinctly different amelogenesis imperfecta phenotypes, ${ }^{67}$ suggesting that these proteins perform unique and critical functions during enamel formation.

Besides ENAM and AMELX, a number of other genes critical to enamel formation have been identified and proposed as candidates for amelogenesis imperfecta, including ameloblastin (AMBN on 4q21; OMIM 601259), ${ }^{19}$ tuftelin, (TUFT1 on chromosome lq21; OMIM 600087), ${ }^{20}$ and two genes for enamel related proteinases: enamelysin (MMP20 on 11q22q23; OMIM 604629) and kallikrein 4 (KLK4 on 19q13; OMIM 603767). ${ }^{21}{ }^{22}$ These proteinases are believed to regulate the enamel matrix protein processing that ultimately defines the structure and composition of enamel. ${ }^{23}$ Abnormal proteolytic processing of the enamel matrix proteins has been postulated to be the principal developmental mechanism associated with the autosomally inherited forms of hypomaturation amelogenesis imperfecta. ${ }^{8}$ Indeed, teeth from individuals with autosomal recessive hypomaturation amelogenesis imperfecta show retention of amelogenin proteins supporting a proteinase or protein processing defect. ${ }^{24} 25$ Mice lacking normal MMP2O activity have hypoplastic and poorly mineralised enamel. ${ }^{26}$ To date there have been no human mutations identified in MMP20 or KLK4. 
In this report, we describe the first mutation in the $K L K 4$ gene and its association with autosomal recessive hypomaturation amelogenesis imperfecta. These findings indicate that kallikrein 4 plays a critical role in normal enamel formation and provides additional evidence for genetic heterogeneity for autosomal recessive amelogenesis imperfecta.

\section{MATERIALS AND METHODS}

\section{Family and phenotype analyses}

This study was approved by the University of North Carolina and the University of Pittsburgh Institutional Review Board. All participants provided written consent prior to enrolment. The family shown in fig IA was ascertained from an affected proband (II-1) who had generally yellow brown enamel (fig 1B). All available family members were examined clinically and radiographically to determine affected status and to characterise the clinical phenotype.
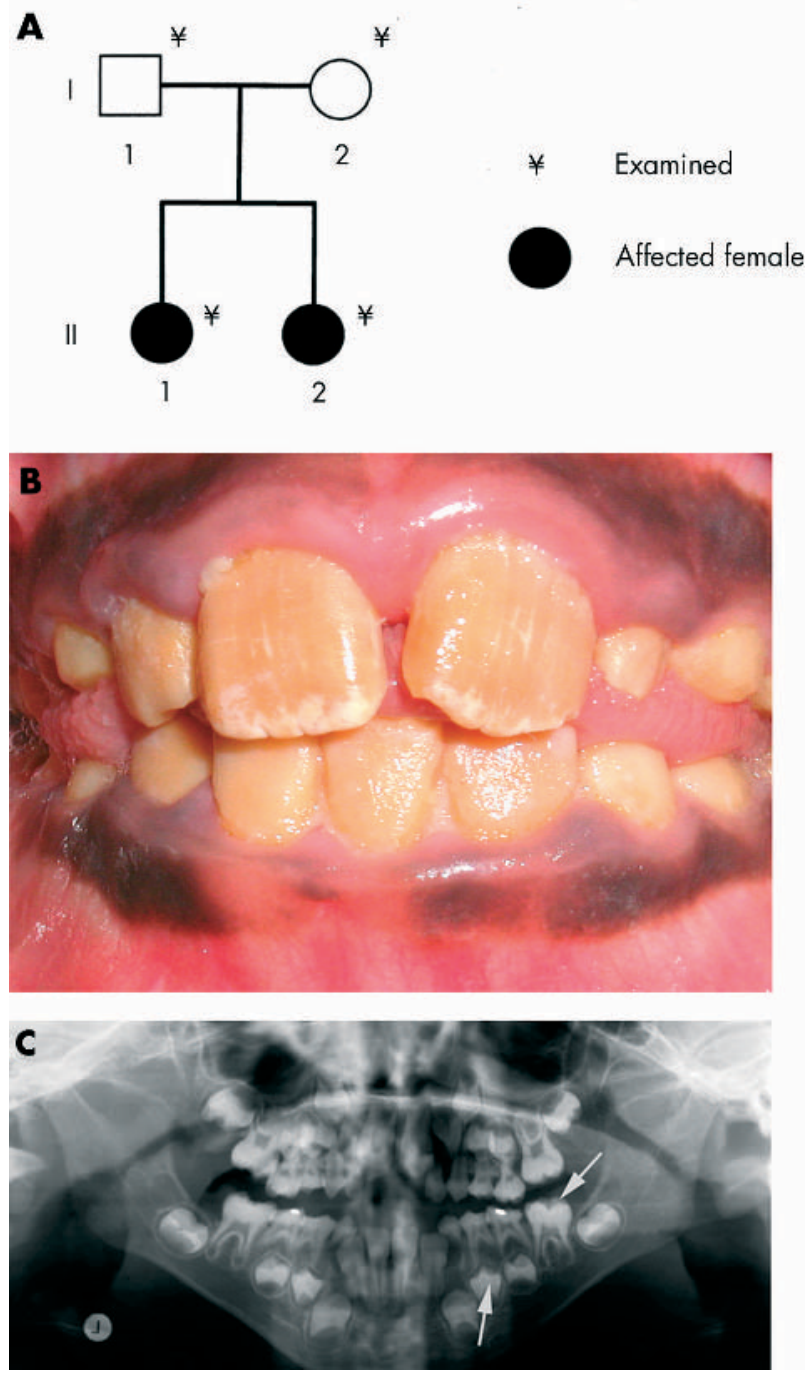

Figure 1 The family pedigree (A) had two affected female children born to two unaffected adults. The dentition of both affected children was normal in morphology but had a generally yellow brown colour (B) that affected both the primary and permanent teeth. Panographic radiography $(C)$ revealed worn and fractured enamel on the posterior teeth and enamel that had a reduced opacity that was only slightly greater than the underlying dentin (arrows), indicative of enamel hypomineralisation.

\section{Molecular studies}

Genomic DNA was isolated from peripheral blood leucocytes from the two affected siblings using the QIAamp blood kit (Qiagen, Santa Clara, CA) as previously reported. ${ }^{27}$ All six exons of KLK4 were amplified using the primers shown in table 1 . PCR was performed in a volume of $50 \mu \mathrm{l}$ containing $0.6 \mu \mathrm{M}$ each of forward and reverse primers, $0.2 \mathrm{mM}$ dNTPs, $2.5 \mathrm{mM} \mathrm{MgCl}_{2}, 1 \times$ PCR buffer, $200 \mathrm{ng}$ DNA, 1 unit of Taq DNA polymerase and either $3 \mu \mathrm{l}$ DMSO (exons 1, 5, and 6) or $3 \mu \mathrm{l}$ PCR enhancer (exons 2, 3, and 4; Invitrogen, Carlsbad, CA). PCR was performed by an initial denaturation at $95^{\circ} \mathrm{C}$ for 1 min then $94^{\circ} \mathrm{C}$ for 3 minutes, followed by 35 cycles of denaturation at $94^{\circ} \mathrm{C}$ for $35 \mathrm{~s}$, annealing for $1 \mathrm{~min}$ at the temperatures listed in table 1 , extension at $72^{\circ} \mathrm{C}$ for $1 \mathrm{~min}$, followed by a final extension at $72^{\circ} \mathrm{C}$ for $10 \mathrm{~min}$. PCR products were electrophoresed through $1 \%$ agarose gels and the amplicons extracted using the Qiagen gel extraction kit. Extracted amplicons were sequenced using ABI Big Dye terminator chemistry and an ABI 3730 DNA analyser. PCR products were sequenced in both directions to minimise sequencing artefacts.

\section{RESULTS}

The children were healthy with no evidence of abnormal ectodermal tissues, or renal or ocular abnormalities, as have been reported in association with syndromic cases of abnormal enamel formation. ${ }^{28}{ }^{29}$ One of the children (II-2) was cognitively delayed while the proband (II-1) was developmentally normal. Dental examination of the parents showed no evidence of any enamel malformation. The parents denied knowledge of consanguinity. The proband had one sibling who was also affected with a nearly identical dental phenotype (fig lA). Both the primary and permanent dentitions in the proband and sibling (ages 9 and 10 years) were similarly affected showing a yellow brown discoloration (fig lB). The teeth were excessively sensitive to hot and cold, making it painful to masticate. Radiographically the teeth appeared morphologically normal in shape indicating that the enamel was of normal thickness (fig lC). The enamel showed only a slightly increased opacity compared with the dentin, indicative of a decreased enamel mineral content. Enamel of the affected children had fractured from the occlusal surfaces of the primary molars, which is consistent with a decreased mineral content. One affected child (II-2) had an anterior dental open bite while the other child (II-1) did not.

The hypomaturation phenotype and apparent autosomal recessive mode of inheritance observed in this family led us to use a candidate gene approach and sequence the KLK4 gene directly. All six exons, including the intron-exon boundaries, were sequenced. A total of three coding region sequence alterations were found, all of which were homozygous in both affected children (table 2). The synonymous p.S100S (g.1984C>T; refSNP ID: rs198966) and non-synonymous p.S22A (g.1327T $>$ G; refSNP ID: rs 1654551) single nucleotide polymorphisms are known sequence alterations of KLK4. The minor allele frequency of the g.1984C $>$ T single nucleotide polymorphism in 134 control African-American chromosomes was 7\%. The p.W153X mutation (fig 2B) is predicted to be causative in the siblings. This nonsense mutation occurs at a tryptophan residue that is completely conserved across KLK4 proteins in mouse and pig, and across all 15 human kallikrein proteins. ${ }^{30}$ The resultant truncated protein would lack the final 101 amino acids, including several functionally important and highly conserved domains, including the S207 of the catalytic triad (figure 2B). This sequence alteration was not found in the 134 African-American control chromosomes tested. 


\begin{tabular}{|c|c|c|c|}
\hline Exon & Sequence & Annealing temperature, ${ }^{\circ} \mathrm{C}$ & Product size, bp \\
\hline 1 & $\begin{array}{l}\text { F 5'- TGGAAGTTGGAGCACCTGA -3' } \\
\text { R 5'- GCGACATGGAGCTGTAGGGA -3' }\end{array}$ & 62 & 227 \\
\hline 2 & $\begin{array}{l}\text { F 5'- CTCATCCCCAGGTGCTGACGT -3' } \\
\text { R 5'- GCCATGGGGGACGGATAACA -3' }\end{array}$ & 58 & 222 \\
\hline 3 and 4 & $\begin{array}{l}\text { F 5'- GCCCCCAGCCCTGACTCG -3' } \\
\text { R 5'-TCACGCACTGCAGCACGGTA -3' }\end{array}$ & 62 & 1195 \\
\hline 5 & $\begin{array}{l}\text { F 5'- GAGGTCCTCTGCCCAGTCG -3' } \\
\text { R 5'-ATGGTAAGGCTCCCCGTCA -3' }\end{array}$ & 58 & 550 \\
\hline 6 (set 1) & $\begin{array}{l}\text { F 5'- TATGTCGCTGGGCTATGTTG-3' } \\
\text { R 5'- GGCCTGGACGGIITCTC-3' }\end{array}$ & 58 & 281 \\
\hline 6 (set 2) & $\begin{array}{l}\text { F 5'- TGGCGTGCCAGGTGTCTA -3' } \\
\text { R 5'- ATGGAAGGGGAAGCAAGGAG -3' }\end{array}$ & 62 & 761 \\
\hline
\end{tabular}

\section{DISCUSSION}

Kallikrein 4, initially called enamel matrix serine proteinase, was originally isolated from developing porcine enamel and thought to be expressed only in developing teeth. ${ }^{22}$ Human $K L K 4$ maps to chromosome $19 \mathrm{q} 13.4$, a region that contains 15 tissue kallikrein genes. ${ }^{28}$ Subsequently several groups independently isolated the human KLK4 gene and cDNA sequences from prostate and a variety of other tissues, including testis, breast, colon, thyroid, uterus, and central nervous system tissue. ${ }^{31-33}$ Recently, KLK4 has been shown to be expressed in skin. ${ }^{1}$ The specific function of the kallikrein 4 proteinase in these different tissues is not known.

During enamel formation kallikrein 4 is known to be secreted by both odontoblasts that form the dentin and ameloblasts that form the enamel. ${ }^{22}{ }^{34}$ Kallikrein 4 is thought to be the predominant enzyme that degrades enamel proteins during the maturation stage of development, and has been shown to cleave amelogenin (the most abundant enamel protein). ${ }^{35}{ }^{36}$ Kallikrein 4 is secreted as an inactive zymogen of 230 amino acids that can be activated by MMP20 through the removal of a 6 amino acid propeptide. ${ }^{35}$ The characteristic triad of catalytic amino acids (H71, D1 16, and S207) is conserved between species and believed to be critical to its proteolytic function. ${ }^{1}$ The human $K L K 4$ gene consists of six exons, five of which are coding. ${ }^{37}$

The enamel phenotype observed in this family is consistent with a loss of kallikrein 4 function and its purported role in enamel mineralisation as well as its known temporal and spatial pattern of expression. The transcript produced by the g. $2142 \mathrm{G}>\mathrm{A}$ mutation would result in a 153 amino acid protein that lacks the S207 of the catalytic triad that is essential for proteolytic activity (fig 2B). The truncated
A 1. Wild-type

\section{A G A C C C CA G C CA G A A A C}

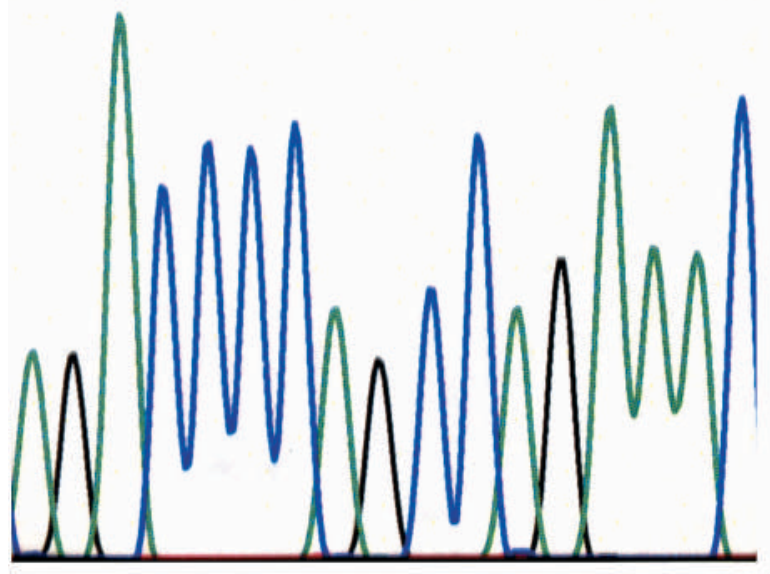

B

Wild-type:

Alternative splice:

Mutant:

Figure 2 Mutational analysis of KLK4. A. Portion of exon 4 sequenced with the reverse primer shown in table 1. 1) Wild-type sequence. 2) Sequence from an affected individual showing the nonsense mutation (g.2142G $>A ; C>T$ on reverse sequence). B. Predicted effect of mutation on the kallikrein 4 protein. The top is a portion of the 254 amino acid wild-type protein. The middle is a normal splice variant that lacks exon 4 , resulting in premature termination and a truncated protein of 159 amino acids. The bottom is the consequence of the mutation which results in a truncated protein of 152 amino acids.

\section{2. g. $2142 \mathrm{G}>\mathrm{A}$}
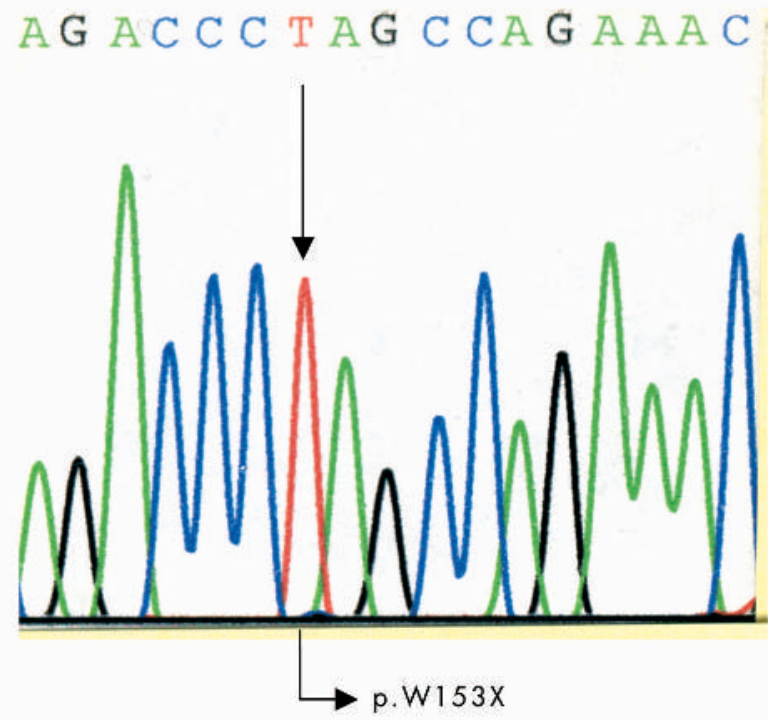

Exon 4

$$
\begin{aligned}
& \ldots L \vee S G W G L L A N G R M P T \vee L \ldots Q A S X \\
& \ldots L \vee S G W G L A N G X
\end{aligned}
$$$$
\text { .. L V S G X }
$$ 
Table $2 \quad K L K 4$ coding region sequence alterations detected in affected siblings

\begin{tabular}{llll}
\hline Exon & Genomic DNA & c.DNA $^{\dagger}$ & Protein $^{\ddagger}$ \\
\hline 3 & g. $1327 T>$ G & c. $64 T>$ G & p.S22A \\
4 & g. 1984 C $>$ T & c. $300 C>$ T & p.S100S \\
4 & g. $2142 \mathrm{G}>$ A & c. $458 G>$ A & p.W153X
\end{tabular}

*Reference sequence GenBank accession no AF228497; the A of the initiator ATG is taken as +1 .

tReference sequence GenBank accession no NM_004917; the A of the initiator ATG is taken as +1

FInitiator methionine at the +1 position.

product would also lack the conserved asparagine and glycine encoded by exon 6 that characterise the binding pocket that defines substrate specificity. ${ }^{1}$ The loss of the S207 site as well as the binding pocket makes it unlikely that the mutant protein (p.W153X) would be functional and process the enamel matrix proteins in a kinetically normal manner. During enamel formation MMP20 is expressed predominantly during the secretory and transitional stages and is believed to be responsible for the early and essential processing of amelogenin. ${ }^{38}{ }^{39}$ During this time much of the enamel matrix is removed and the enamel crystallites grow to achieve approximately $40-60 \%$ mineral per volume. ${ }^{40}{ }^{41}$ The loss of kallikrein 4 function would primarily interfere with the maturation stage of enamel development when it is maximally expressed. ${ }^{36}$ Previous studies have shown that autosomal recessive hypomaturation amelogenesis imperfecta teeth have a marked retention of enamel matrix proteins and amelogenin resulting in a dramatic reduction of mineral content. ${ }^{24}{ }^{42}$ The clinical phenotype characterised by enamel loss and a marked reduction in radiographic enamel opacity is consistent with the enamel being hypomineralised similar to cases we have previously reported (no teeth were available from this family for analysis). The enamel in the affected individuals had a normal enamel thickness indicating that the enamel matrix was secreted in a relatively normal amount and, although the enamel appeared radiographically hypomineralised, it was mineralised to a greater extent than the dentin (dentin is normally $55-60 \%$ mineral per volume). Collectively, this indicates that the enamel crystallites grew to a normal length producing enamel of normal thickness, however the crystallites failed to grow completely in their thickness or width, probably because of retention of enamel proteins, thereby producing a hypomineralised enamel. Taken together, these findings indicate that a loss of kallikrein 4 function primarily affected the maturation stage of enamel development and resulted in the enamel crystallites not achieving the final growth that would have allowed the final deposition of an additional 15$20 \%$ mineral.

Interestingly, an alternative splice product lacking exon 6 (the fifth coding exon) is the predominant kallikrein 4 transcript in skin and has also been described in human endometrial tumour cultures. ${ }^{143}$ This alternative splice product would result in a truncated protein of 159 amino acids that would lack the catalytic S207 and the binding pocket that defines substrate specificity and is therefore not expected to encode a protein with proteolytic activity. ${ }^{32}{ }^{36} \mathrm{At}$ this time, the role of the alternative splice product is not known. The protein encoded by this natural splice variant is very similar to the protein encoded by the g.2142G $>$ A mutation (fig 2B). The limitation of the phenotype to enamel in the affected individuals in this family suggests that kallikrein 4 may have distinctly different functions or redundancies in different tissues. Splice variants as discussed above could potentially have functionality in some tissues but not others. The focused phenotype may also be explained by there being limited kallikrein genes expressed in developing enamel (only kallikrein 4 has been localised to enamel), while all other tissues studied have been shown to express multiple kallikrein genes (for example, skin expresses $K L K 1$, KLK4, KLK5, KLK6, KLK7, KLK8, KLK11, and KLK13). ${ }^{32}$

The rarity of autosomal recessive hypomaturation amelogenesis imperfecta in the population suggests that mutations in the KLK4 gene are not common. ${ }^{5}$ The finding that the affected individuals were homozygous for the g.2142G $>$ A mutation raises the possibilities of consanguinity, a founder effect, or a mutational hotspot in KLK4. Given that all coding region sequence alterations (table 2 ) were homozygous in the affected individuals, these results would argue against a mutational hotspot and for alleles inherited identical by descent.

In summary, the g. $2142 \mathrm{G}>\mathrm{A}$ mutation is the first mutation reported in the human KLK4 gene and represents the first mutation found to cause autosomal recessive hypomaturation amelogenesis imperfecta. This is the first mutation in a proteinase involved in enamel matrix processing and substantiates the previous hypothesis of Witkop and Sauk that a protease defect could underlie autosomal recessive pigmented hypomaturation amelogenesis imperfecta. ${ }^{5}$ These results also indicate that normal kallikrein 4 function is critical for enamel mineralisation. Mutations in three genes (KLK4, ENAM, and AMELX) have now been demonstrated to result in amelogenesis imperfecta. Continued mutational analysis of families with amelogenesis imperfecta will allow a comprehensive standardised nomenclature system to be developed for this group of disorders that will include molecular delineation as well as mode of inheritance and phenotype.

\section{Authors' affiliations \\ P S Hart, NHGR \\ T C Hart, NIDCR \\ M D Michalec, O H Ryu, University of Pittsburgh \\ D Simmons, S Hong, J T Wright, University of North Carolina}

Funding: NIDCR Grant 12879 and CRDF award (University of Pittsburgh)

Conflict of interest: none declared.

Correspondence to: Professor J Timothy Wright, Braver Hall CB 7450 Department of Pediatric Dentistry, School of Dentistry Chapel Hill, United States; tim_wright@dentistry.unc.edu

Received 16 December 2003

Accepted for publication 27 January 2004

\section{REFERENCES}

1 Komatsu N, Takata M, Otsuki N, Toyama T, Ohka R, Takehara K, Saijoh K. Expression and localization of tissue kallikrein mRNAs in human epidermis and appendages. J Invest Dermatol 2003;121:542-9.

2 Wong GW, Yasuda S, Morokawa N, Li L, Stevens RL. Mouse chromosome 17A3.3 contains thirteen genes that encode functional tryptic-like serine proteases with distinct tissue and cell expression patterns. J Biol Chem 2003:279:2438-52

3 Molinari F, Rio M, Meskenaite V, Encha-Razavi F, Auge J, Bacq D, Briault S, Vekemans M, Munnich A, Attie-Bitach T, Sonderegger P, Colleaux L. Truncating neurotrypsin mutation in autosomal recessive nonsyndromic mental retardation. Science 2002;298:1779-81.

4 Holzinger A, Maier EM, Buck C, Mayerhofer PU, Kappler M, Haworth JC, Moroz SP, Hadorn HB, Sadler JE, Roscher AA. Mutations in the proenteropeptidase gene are the molecular cause of congenital enteropeptidase deficiency. Am J Hum Genet 2002;70:20-5.

5 Witkop Jr CJ. Amelogenesis imperfecta, dentinogenesis imperfecta and dentin dysplasia revisited: problems in classification. J Oral Pathol 1988;17:547-53.

6 Wright JT, Hart PS, Aldred MJ, Seow WK, Crawford PJM, Hong SP, Gibson C, Hart TC. Relationship of phenotype and genotype in X-linked amelogenesis imperfecta. Connect Tissue Res 2003:44(suppl 1):72-8.

7 Hart PS, Michalec MD, Seow WK, Hart TC, Wright JT. Identification of the enamelin (g.8344delG) mutation in a new kindred and presentation of a standardized ENAM nomenclature. Arch Oral Biol 2003;48:589-96. 
8 Witkop CJ, Sauk JJ. Heritable defects of enamel. In: Stewart R, Prescott G, eds. Oral Facial Genetics. St Louis: CV Mosby Company, 1976:151-226.

9 Sundell S. Hereditary amelogenesis imperfecta. An epidemiological, genetic and clinical study in a Swedish child population. Swed Dent J Suppl 1986;31:1-38.

10 Backman B, Holm AK. Amelogenesis imperfecta: prevalence and incidence in a northern Swedish county. Community Dent Oral Epidemiol 1986;14:43-7.

11 Chosack A, Eidelman E, Wisotski I, Cohen T. Amelogenesis imperfecta amon Israeli Jews and the description of a new type of local hypoplastic autosoma recessive amelogenesis imperfecta. Oral Surg Oral Med Oral Pathol 1979;47:148-56.

12 Robinson C, Briggs HD, Atkinson PJ, Weatherell JA. Matrix and mineral changes in developing enamel. J Dent Res 1979;58:871-82.

13 Robinson C, Shore RC, Kirkham J, Stonehouse NJ. Extracellular processing of enamel matrix proteins and the control of crystal growth. J Biol Buccale 1990; 18:355-61.

14 Simmer JP, Fincham AG. Molecular mechanisms of dental enamel formation. Crit Rev Oral Biol Med 1995;6:84-108.

15 Fincham AG, Lau EC, Simmer J, Zeichner-David M. Amelogenin biochemistry - form and function. In: Slavkin $\mathrm{H}$, Price $\mathrm{P}$, eds. Chemistry and biology of mineralized tissues. Amsterdam: Elsevier Science, 1992:187-201

16 Fukae M, Tanabe T, Uchida T, Yamakoshi Y, Shimizu M. Enamelins in the newly formed bovine enamel. Calcif Tissue Int 1993;53:257-61

17 Hu JC-C, Sun X, Zhang C, Simmer JP. A comparison of enamelin and amelogenin expression in developing mouse molars. Eur J Oral Sci 2001;109:125-32.

18 Hu C-C, Simmer JP, Bartlett JD, Qian Q, Zhang C, Ryu OH, Xue J, Fukae M, Uchida T, MacDougall MJ. Murine enamelin: CDNA and derived protein sequences. Connect Tissue Res 1998:39:351-65.

19 Krebasbach PH, Lee SK, Matsuki Y, Kozak CA, Yamada KM, Yamada Y. Fulllength sequence, localization, and chromosomal mapping of ameloblastin. $J$ Biol Chem 1996;271:4431-5.

20 Deutsch D, Palmon A, Fisher LW, Kolodny N, Termine JD, Young MF. Sequencing of bovine enamelin ("tuftelin") a novel acidic enamel protein. J Biol Chem 1991;266:16021-8

21 Bartlett JD, Simmer JP, Xue J, Margolis HC, Moreno EC. Molecular cloning and mRNA tissue distribution of a novel matrix metalloproteinase isolated from porcine enamel organ. Gene 1996;183:123-8.

22 Simmer JP, Fukae M, Tanabe T, Yamakoshi Y, Uchida T, Xhu J, Margolis HC, Shimizu M, BC D, Hu C-C, Bartlett J. Purification, characterization and cloning of enamel matrix serine proteinase 1. J Dent Res 1998;77:377-86.

23 Bartlett JD, Simmer JP. Proteinases in developing dental enamel. Crit Rev Oral Biol Med 1999; 10:425-41

24 Wright JT, Butler WT. Alteration of enamel proteins in hypomaturation amelogenesis imperfecta. J Dent Res 1989;68:1328-30.

25 Wright JT, Hall K, Yamauchi M. The protein composition of normal and developmentally defective enamel. In: Chadwick DJ, Cardew G, eds. Dental enamel. Chichester: Wiley, 1997:85-99.

26 Caterina JJ, Skobe Z, Yanli Ding J-S, Simmer JP, Birkedal-Hansen H, Bartlett JD. Enamelysin (matrix metalloproteinase 20)-deficient mice display an amelogenesis imperfecta phenotype. J Biol Chem 2002;277:49598-604

27 Zhang Y, Hart PS, Moretti AJ, Bouwsma OJ, Fisher EM, Dudlicek L, Pettenati MJ, Hart TC. Biochemical and mutational analyses of the cathepsin c gene (CTSC) in three North American families with Papillon Lefèvre syndrome. Hum Mutat 2002;20:75.

28 Downey LM, Keen TJ, Jalili IK, McHale J, Aldred MJ, Robertson SP, Mighell A, Fayle S, Wissinger B, Inglehearn CF. Identification of a locus on chromosome $2 q 11$ at which recessive amelogenesis imperfecta and cone-rod dystrophy cosegregate. Eur J Hum Genet 2002;10:865-9.

29 Normand de la Tranchade I, Bonarek H, Marteau JM, Boileau MJ, Nancy J. Amelogenesis imperfecta and nephrocalcinosis: a new case of this rare syndrome. J Clin Pediatr Dent 2003;27:171-5.

30 Yousef GM, Diamandis EP. The new human tissue kallikrein gene family: structure, function, and association to disease. Endocr Rev 2001;22:184-204.

31 Nelson PS, Gan L, Ferguson C, Moss P, Gelinas R, Hood L, Wang K. Molecular cloning and characterization of prostase, an androgen-regulated serine protease with prostate-restricted expression. Proc Natl Acad Sci U S A 1999;96:3114-9.

32 Stephenson SA, Verity K, Ashworth LK, Clements JA. Localization of a new prostate-specific antigen-related serine protease gene, KLK4, is evidence for an expanded human kallikrein gene family cluster on chromosome 19q13.313.4. J Biol Chem 1999;274:23210-4.

33 Yousef GM, Luo LY, Diamandis EP. Identification of novel human kallikrein-like genes on chromosome 19q13.3-q13.4. Anticancer Res 1999:19:2843-52.

34 Nagano T, Oida S, Ando H, Gomi K, Arai T, Fukae M. Relative levels of mRNA encoding enamel proteins in enamel organ epithelia and odontoblasts. $J$ Dent Res 2003;82:982-6.

35 Ryu O, Hu JC, Yamakoshi Y, Villemain JL, Cao X, Zhang C, Bartlett JD Simmer JP. Porcine kallikrein-4 activation, glycosylation, activity, and expression in prokaryotic and eukaryotic hosts. Eur J Oral Sci 2002; 110:358-65.

36 Simmer JP, Hu JC. Expression, structure, and function of enamel proteinases. Connect Tissue Res 2002:43:441-9.

37 Hu C, Hart T, Dupont B, Chen J, Jiang H, Sun X, Qian Q, Zhang C, Wright T, Simmer J. Cloning human enamelin CDNA, chromosomal localization and analysis of expression during tooth development. J Dent Res 2000;79:912-9.

38 Bartlett JD, Ryu OH, Xue J, Simmer JP, Margolis HC. Enamelysin mRNA displays a developmentally defined pattern of expression and encodes a protein which degrades amelogenin. Connect Tissue Res 1998;39:405-13.

39 Ryu OH, Fincham AG, Hu CC, Zhang C, Qian Q, Bartlett JD, Simmer JP. Characterization of recombinant pig enamelysin activity and cleavage of recombinant pig and mouse amelogenins. J Dent Res 1999;78:743-50.

40 Deutsch D, Alayoff A. Changes in amino acid composition and protein distribution during development of human deciduous enamel. Growth 1987:51:342-54.

41 Robinson C, Kirkham J, Hallsworth AS. Volume distribution and concentration of protein, mineral and water in developing bovine enamel. Arch Oral Biol 1988;33:159-62

42 Wright JT, Deaton TC, Hall Kl, Yamauchi M. The mineral and protein content of enamel in amelogenesis imperfecta. Connect Tissue Res 1995;31:247-52.

43 Myers SA, Clements JA. Kallikrein 4 (KLK4), a new member of the human kallikrein gene family is up-regulated by estrogen and progesterone in the human endometrial cancer cell line, KLE. J Clin Endocrinol Metab 2001;86:2323-6. 